\title{
Investigating Work Engagement of Highly Educated Young Employees through Applying the Job Demands-Resources Model
}

\author{
Widdy Muhammad Sabar Wibawa ${ }^{1}$, Yoshi Takahashi2* ${ }^{2}$, Corina D. Riantoputra ${ }^{3}$
}

${ }^{1}$ Graduate School for International Development and Cooperation, Higashihiroshima, Hiroshima University, Japan

${ }^{2 *}$ Graduate School of Humanities and Social Sciences, Higashihiroshima, Hiroshima University, Japan

${ }^{3}$ Faculty of Psychology, Universitas Indonesia, Depok, Jawa Barat, Indonesia

\begin{tabular}{|c|c|}
\hline & ABSTRACT \\
\hline $\begin{array}{l}\text { Keywords: } \\
\text { Work Engagement, JD-R } \\
\text { Model, Perceived } \\
\text { Organizational Support, } \\
\text { Employee Voice, Emotional } \\
\text { Demands }\end{array}$ & $\begin{array}{l}\text { This study aims to investigate the applicability of the job demands and resources (JD-R) } \\
\text { model. While prior studies tend to focus on older employees, we investigate the potentially } \\
\text { effective job resources and demands specifically for the highly educated young individuals } \\
\text { that are the future of any organization. We collected primary cross-sectional data from } 155 \\
\text { respondents in Indonesia with master's or doctoral degrees, under } 40 \text { years of age, currently } \\
\text { working in public and private sectors. Participants completed an online questionnaire by }\end{array}$ \\
\hline Received & relationships between job resources (perceived organizational support (POS) and employee \\
\hline 13 February 2021 & voice), job demands (emotional demands), and work engagement. Our results indicated the \\
\hline $\begin{array}{l}\text { Received in revised form } \\
01 \text { March } 2021 \\
\text { Accepted } \\
04 \text { March } 2021 \\
\end{array}$ & $\begin{array}{l}\text { relationships for POS positively and emotional demands negatively with work engagement, } \\
\text { while employee voice was not significantly correlated with work engagement. Emotional } \\
\text { demands are considered to be perceived as stress rather than opportunity. Furthermore, } \\
\text { emotional demands did not moderate the correlation of POS and employee voice with work }\end{array}$ \\
\hline $\begin{array}{l}\text { *Correspondence: } \\
\text { yoshit@hiroshima-u.ac.jp }\end{array}$ & $\begin{array}{l}\text { the private and public sectors. The results showed the JD-R model was partially applicable. } \\
\text { This study is one of few seeking to apply the JD-R model to highly educated young employees } \\
\text { in the private and public sectors. The specific results of this study will provide insight for the } \\
\text { organizations employing such individuals. }\end{array}$ \\
\hline
\end{tabular}

CCIKD Publishing

Work engagement is "a positive, fulfilling, work-related state of mind that is characterized by vigor, dedication, and absorption" (Schaufeli et al., 2002, p. 72). It plays a major part in many discussions 
in human resource management (HRM) research (Arrowsmith \& Parker, 2013). Work engagement is also a key factor in an organization's sustainability and competitiveness (Saks \& Gruman, 2014), as it influences individual and organizational performance (Hoole \& Bonnema, 2015). Engaged employees tend to show more positive emotions, optimism, and enthusiasm. Moreover, they can also use better their personal resources; have better health; and tend to transmit engagement to other people in their work environment (Bakker, 2011; Ferreira et al., 2020; Nguyen \& Pham, 2020).

Although there is a lack of consensus among researchers regarding the most effective theory for analyzing work engagement, the job demands and resources (JD-R) model has been often used in the empirical studies of engagement (Saks \& Gruman, 2014). Bakker and Demerouti (2007) argued that this model is useful for HRM, as the organization can change job demands and resources. Furthermore, the JD-R model can reveal influencing factors and results of work engagement and is popular due to its flexibility (Bakker et al., 2014).

Since there is an increasing number of young employees to enter the workforce, particularly in Indonesia, there is a need to understand work engagement for young professionals. However, previous research focused largely on older employees (Avery et al., 2007; Kulik et al., 2016; Mauno $\&$ Minkkinen, 2020). Younger individuals tend to have lower engagement than older individuals (Park \& Gursoy, 2012). There is a need to uncover factors that contribute to young employees' engagement. Thus, this study investigates the applicability of the JD-R model for younger employees. These employees have different tendencies in perceiving demands.

We focus on those with a minimum of a master's degree because we expect that people with a higher education level tend to have higher aspirations and different expectations in organizations based on their competitive advantages. At the same time, organizations may be interested in hiring and retaining highly educated employees for their innovation and sustainability. Thus, understanding how to improve work engagement in highly educated employees is crucial for organizations.

Employing the lens of JD-R model, we aim to understand how highly educated young employees tend to perceive their demands. Crawford et al. (2010) argued employees may perceive workplace demands as positive (challenges or opportunities) or as negative (stressful event), with varying effects on work engagement. Perceiving demands as stress is likely to negatively influence work engagement. On the other hand, perceiving demands as opportunities is likely to positively influence work engagement. This study aims to elucidate the effect of job demands on highly educated young employees, considering whether demands are perceived as opportunities or stress. Investigating this will be beneficial for future organizational practice on handling these types of employees.

Further, previous research focuses on work engagement in the private rather than the public sector (Vigoda-Gadot et al., 2013). These two sectors differ significantly (Byrne \& MacDonagh, 2017; Knies et al., 2015), for example, in terms of their organizational structure and their employees' motivation and expectations (Perry et al., 2010). This study aims to address this gap by including employees in both the public and private sectors.

\section{Literature Review}

\section{Work Engagement}

Most research use the definition of work engagement from the study of Schaufeli et al. (2002), measuring the characteristics of work engagement that consist of vigor, dedication, and absorption. Vigor denotes a "high level of energy and mental resilience while working" (p. 74); dedication 
refers to an experience of having a "sense of significance, enthusiasm, inspiration, pride, and challenge" (p. 74); and absorption signifies a "state of being fully concentrated and deeply engrossed in one's work" (p. 75). According to Saks and Gruman (2014), research on engagement in the workplace mainly focuses on measuring it, including its determinants and consequences. Prior research revealed that workplace engagement positively affected work outcomes such as performance at both organizational and individual levels. Considering its importance, prior research also focused on the antecedents of work engagement. One major line of theoretical argument on the antecedents of engagement in the workplace is the JD-R model.

\section{Job Demands and Resources Model}

Drawing upon the theory of conservation of resources theory (COR) (Hobfoll, 1989), individuals attempted to pursue, maintain, and preserve available resources and accumulate all those with continuous positive effect, which is likely to have both positive organizational and individual wellbeing. Hence, individuals who have more experience of resources positively, are likely to stimulate better relationship between individual and organizational well-being.

The JD-R model is a popular theory for investigating the process toward engagement, with the working conditions divided into two aspects: demands and resources (Bakker \& Demerouti, 2007; Byrne \& MacDonagh, 2017). Both job demands and job resources may include physical, social, or organizational aspects. The difference is job demands require employees to invest extra energy into dealing with the stress related to it. In contrast, job resources offer support in organizational support and positive feedback (Schaufeli et al., 2006).

The JD-R model proposes that job demands and resources influence work engagement (Saks \& Gruman, 2014). Bakker et al. (2011) argued that job resources assist work engagement and that insufficient resources may lead to lower engagement, regardless of job demand level (Hakanen et al., 2008). This suggests that adequate perceived resources produce engaged employees. Crawford et al. (2010) also argued job resources were positively related to work engagement. Saks and Gruman (2014) argued that job demands might negatively influence mental and physical resources, leading to disengagement (p. 162). However, Crawford et al. (2010) suggested job demands were positively or negatively related to work engagement, depending on whether they act as an opportunity or a hindrance. Some research based on the JD-R model suggested that the influence of job resources on work engagement is stronger when employees encounter high job demands (Bakker \& Demerouti, 2007; Bakker et al., 2011).

\section{Applicability of the JD-R Model to Highly Educated Young Employees}

There has been still inconclusiveness on the definition of young or old workers (James et al., 2011; Smyer \& Pitt-Catsouphes, 2007). Consequently, this study follows James et al. (2011) who defined young workers as anyone under 40 years of age. They argued that differences in how job conditions are perceived are linked to engagement in different age groups, suggesting that the JD-R model's applicability is different for specific age groups. We predict that young individuals can increase their work engagement by utilizing job resources, but they need more resources than older individuals to engage themselves. Specifically, those who are new to entering a workplace need more time to adapt to the workplace, build new relationships, etc. Hence, even though they are provided the same resources, young individuals' engagement will remain lower compared with older individuals. 
According to Park and Gursoy (2012), younger individuals tend to place higher value on leisure than work and have lower work centrality. It implies that younger individuals will actively seek working environments that give them more flexible time for leisure, and their jobs are not their central priority. Hence, they may be more affected by insufficient job resources. Similarly, Park and Gursoy (2012) found that young individuals are generally less engaged than older individuals. Their results implied that younger individuals are less likely to allocate their job resources to work since they have low work centrality. Furthermore, young employees had to make essential vocational decisions, form new relationships, and adopt new roles (Akkermans et al., 2013; Elfering et al., 2007; Savickas, 1999). These, particularly for employees entering the workplace after graduation or starting their career with little or no prior experience, are likely to make them disengaged because they have less experience facing the new situation. Moreover, in terms of the interaction of job resources and demands, sufficient resources are likely to facilitate engagement as job resources enable employees to cope with job demands. Fewer resources will hinder individuals' ability to cope with job demands, leaving them less engaged.

Among young employees, the highly educated have some specific characteristics compared with the less educated. Organizations generally prefer to hire younger individuals due to assumptions about their flexibility and adaptability to new technologies (Korsakienè et al., 2019). These assumptions may partly be because young workers are more likely to possess higher education in emerging countries like Indonesia. Moreover, highly educated individuals may feel an obligation to prove their capabilities based on their education level while also believing that they deserve a better job. This is similar with "the sense of competence" (Akkermans et al., 2013). We expect that such a sense of competence influences employees' perceptions of workplace demands. The sense of competence of highly educated young employees is likely to make them perceive demands as stress, which can make them less engaged.

\section{Hypothesis Development}

Among many types of job resources, we focus on POS (perceived organizational support); and the ability to contribute to decision-making processes, referred to as employee voice; as these factors were demonstrated to be essential job resources (Byrne \& MacDonagh, 2017; Conway et al., 2016). Organizational support involves action from each management level that indicates to the employees that their work is valued, the organization cares about their well-being, and that support is available for employees to engage with their work, job, or organization (Byrne \& MacDonagh, 2017; Eisenberger et al., 1986). According to Bakker et al. (2007), all aspects, such as appreciation, feedback, autonomy, and performance feedback, affect engagement, although appreciation is the most salient. Byrne and MacDonagh (2017) found that POS has a significant positive correlation with engagement; thus, adequate POS is likely to produce engaged employees. This leads to our first hypothesis:

Hypothesis 1: POS has a positive correlation with work engagement.

Employee voice refers to employees' ability to contribute ideas or opinions and feel heard by the management (Farndale et al., 2011). Employees who feel valued and included in organizational matters by being asked their opinions, ideas, and views are more likely to be engaged (Reissner \& Pagan, 2013). Rees et al. (2013) found that employee voice was significantly positively correlated with engagement. Conway et al. (2016) indicated that the employee voice mechanism acted as a 
job resource, strengthening engagement. On the other hand, Byrne and MacDonagh (2017) found that employee voice did not significantly correlate with engagement. As the majority research suggests a positive correlation, our second hypothesis is:

Hypothesis 2: Employee voice has a positive correlation with work engagement.

We focused on emotional demands that influence work engagement, as research has shown that positive emotion has a positive correlation with engagement. In contrast, negative emotion contributes to strain, resulting in burnout (Schaufeli et al., 2009). According to De Jonge et al. (2008), emotional demands can be defined as emotionally demanding work, such as controlling emotions and facing negative events in the workplace. While physical demands may not be present in all jobs, emotional demands are expected to exist in most workplaces. Furthermore, emotional demands might be perceived by highly educated young employees as an additional stressor, creating a burden. As such, this group is likely to react negatively to these job demands. According to Bakker et al. (2007), the negative relationship of job demands with work engagement may be because employees perceived such demands as stress. Therefore, our third hypothesis is:

Hypothesis 3: Emotional demands have a negative correlation with work engagement.

Moreover, job resources and demands interact with each other in predicting well-being in the workplace (Bakker et al., 2014). The JD-R theory states that the relationship between job resources and work engagement is stronger under high job demands, including cognitive and emotional demands, which has been supported through empirical research (Bakker et al., 2014; Hakanen et al., 2005). Previous research indicates job demands have a moderating effect on the relationship, as job resources are crucial and are used to cope with the high level of job demands. Therefore, we hypothesize that:

Hypothesis 4: Emotional demands positively moderate the relationship between employee voice and work engagement.

Hypothesis 5: Emotional demands positively moderate the relationship between POS and work engagement.

Figure 1 shows our research framework and the testing of the hypotheses based on Bakker (2011).

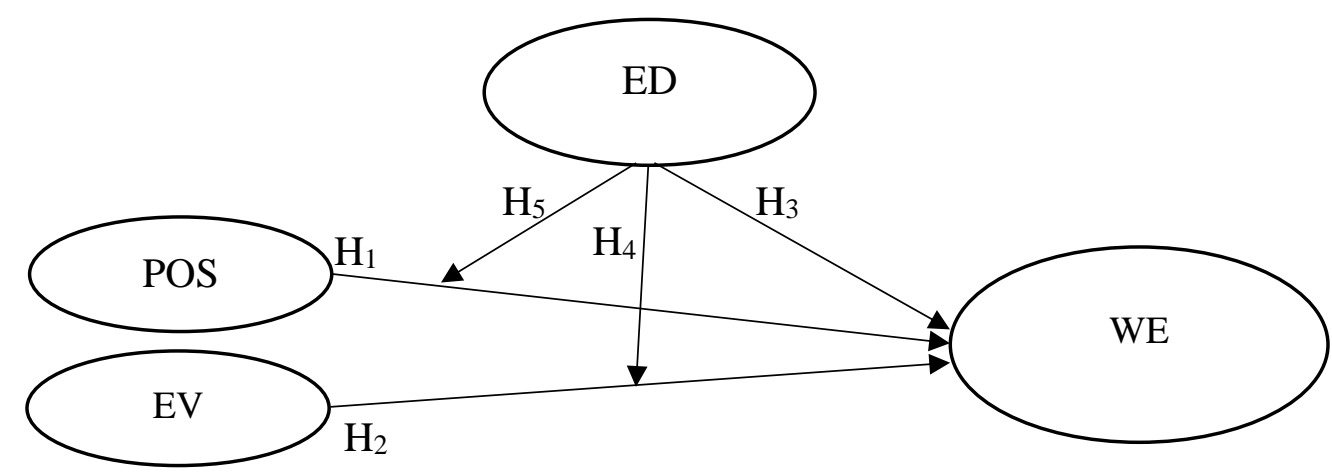

Figure 1. Research framework. 


\section{Method}

\section{Sample and Procedure}

This study collected cross-sectional data through an online questionnaire sent to the awardees of the Indonesia Endowment Fund for Education (LPDP scholarship), a government scholarship for pursuing master's and doctoral degrees, for Indonesian citizens. We chose this group because this scholarship is open to all Indonesian citizens, already has alumni, and has a group email list that made the questionnaires more feasible. The inclusion criteria were individuals below the age of 40 currently working in the private or public sector, excluding self-employed individuals. The participants were invited to take the survey through emails sent to the mailing list of the awardees. Participation was voluntary, and all participants provided informed consent. This study was approved by the Research Ethics Board, Faculty of Psychology, of the Universitas Indonesia.

Data were collected over two weeks during early 2020. In total, 155 respondents participated in the survey, exceeding the minimum required sample size as suggested if we use partial least squares structured equation modeling (PLS-SEM) to perform the data analysis. This study used PLS-SEM to conduct data analysis.

\section{Measurements}

This study used measurements validated through prior studies related to work engagement, job resources (POS and employee voice), and job demands (emotional demands). Questions on work engagement were adopted from the 9-item version of the Utrecht Work Engagement Scale, which includes vigor, dedication, and absorption (Schaufeli et al., 2006). POS was measured using a 9item scale developed by Eisenberger et al. (1986). Employee voice was measured using a 4-item scale developed by Conway et al. (2016). Perceived emotional demands were measured utilizing a 3-item scale from the Copenhagen Psychosocial Questionnaire (COPSOQ) developed by Kristensen and Borg (2003). All questions in the questionnaire were translated into Bahasa Indonesia (the local language) by a professional sworn translator and were back-translated to check the quality of the translation. All items are presented in Table 1.

Table 1

List of Questions

\begin{tabular}{|c|c|c|}
\hline No & Variables & Questions \\
\hline 1 & Work Engagement (WE) & $\begin{array}{l}\text { At my work, I feel bursting with energy } \\
\text { At my job, I feel strong and vigorous } \\
\text { When I get up in the morning, I feel like going to work } \\
\text { I am enthusiastic about my job } \\
\text { My job inspires me } \\
\text { I am proud of the work that I do } \\
\text { I feel happy when I am working intensely } \\
\text { I am immersed in my work } \\
\text { I get carried away when I am working }\end{array}$ \\
\hline 2 & Perceived Organizational Support (POS) & $\begin{array}{l}\text { The organization value my contribution to its well-being } \\
\text { The organization strongly considers my goals and values } \\
\text { Help is available from the organization when I have a problem } \\
\text { The organization really cares about my well-being } \\
\text { The organization is willing to help me when I need a special favor } \\
\text { The organization cares about my general satisfaction at work } \\
\text { The organization cares about my opinions } \\
\text { The organization takes pride in my accomplishment at work } \\
\text { The organization tries to make my job as interesting as possible }\end{array}$ \\
\hline
\end{tabular}




\begin{tabular}{ll}
\hline $3 \quad$ Employee Voice (EV) & $\begin{array}{l}\text { I have good opportunities to participate in decisions that affect me } \\
\text { Suggestions that I make are taken seriously } \\
\text { My organization makes staff aware of future plans that may affect people or their jobs } \\
\text { I have a good deal of information about what is happening in a different part of my } \\
\text { organization }\end{array}$ \\
& $\begin{array}{l}\text { Does your work put you in emotionally disturbing situations? } \\
\text { Is your work emotionally demanding? } \\
\text { Do you get emotionally involved in your work? }\end{array}$ \\
\hline
\end{tabular}

\section{Results}

\section{Demographic Data}

Table 2 shows the demographics of the respondents. Respondents' average age was 30.19 , with the majority in the $28-31$ range $(35.5 \%)$, with the smallest percentage in the $36-39$ group $(9.7 \%)$. The majority of respondents were women (59\%). Most of the participants had a master's degree (95\%), and $60 \%$ worked in the public sector. Furthermore, many of our samples were relatively new in their organization. Many of them were three years or less in their organizations $(85.9 \%)$.

Table 2

Profile of the Respondents

\begin{tabular}{llc}
\hline Description $(\mathrm{n}=155)$ & Frequency & Percentage \\
\hline Age & & \\
$24-27$ & 45 & 29.0 \\
$28-31$ & 55 & 35.5 \\
$32-35$ & 40 & 25.8 \\
$36-39$ & 15 & 9.7 \\
Gender & & \\
Male & 63 & 41.0 \\
Female & 92 & 59.0 \\
Educational level & & \\
Master's degree & 148 & 95.5 \\
Doctoral degree & 7 & 4.5 \\
Working place & & \\
Public & 93 & 60.0 \\
Private & 62 & 40.0 \\
Working duration & & \\
$<=1$ year & 72 & 46.5 \\
$1-3$ years & 61 & 39.4 \\
$>3$ years & 22 & 14.2 \\
\hline
\end{tabular}

\section{Testing the Model of Measurement}

Based on previous research, this study analyzed the data utilizing the PLS-SEM using Software Smart PLS 3. We investigated the hypotheses and conducted a multiple group analysis to observe correlations across private and public sectors. PLS-SEM was utilized because it can accommodate small sample sizes with the non-normal distribution of variables, does not require many assumptions, and is used for theory confirmation and investigation of relationships between variables in formative constructs (Falk \& Miller, 1992). Due to the relatively small number of samples, we used the t-test to check for the late response bias and found that the result was satisfactory.

We conducted the assessment of the measurement model and structural model (Chin, 1998), checking the measurement model by conducting tests of internal consistency/reliability, convergent 
validity, and discriminant validity (Hair et al., 2016; Ong \& Bahar, 2019). The results are displayed in Table 3.

Table 3

Result of the Measurement Model

\begin{tabular}{|c|c|c|c|c|c|}
\hline Constructs & Indicators & Loadings & Cronbach's $\alpha$ & Composite reliability & AVE \\
\hline \multirow[t]{8}{*}{ Work engagement } & WE1 & .89 & .93 & .94 & .69 \\
\hline & WE2 & .89 & & & \\
\hline & WE3 & .76 & & & \\
\hline & WE4 & .90 & & & \\
\hline & WE5 & .88 & & & \\
\hline & WE6 & .85 & & & \\
\hline & WE7 & .78 & & & \\
\hline & WE9 & .63 & & & \\
\hline \multirow[t]{9}{*}{ Perceived organizational supports } & POS1 & .87 & .96 & .96 & .77 \\
\hline & POS2 & .88 & & & \\
\hline & POS3 & .88 & & & \\
\hline & POS4 & .84 & & & \\
\hline & POS5 & .88 & & & \\
\hline & POS6 & .91 & & & \\
\hline & POS7 & .88 & & & \\
\hline & POS8 & .87 & & & \\
\hline & POS9 & .87 & & & \\
\hline \multirow[t]{4}{*}{ Employee voice } & EV1 & .87 & .86 & .92 & .71 \\
\hline & EV2 & .88 & & & \\
\hline & EV3 & .91 & & & \\
\hline & EV4 & .68 & & & \\
\hline \multirow{2}{*}{ Emotional demand } & ED1 & .94 & .68 & .85 & .74 \\
\hline & ED2 & .77 & & & \\
\hline M. Effect 1 & $\mathrm{EV} * \mathrm{WE}$ & .11 & & & \\
\hline M. Effect 2 & POS*WE & -.09 & & & \\
\hline
\end{tabular}

As suggested by Chin (1998), the indicator loading value should be above .6 (the cut-off value). Therefore, items with the outer loading below .6 were removed from the main analysis. We assessed the remaining items for internal reliability with Cronbach's $\alpha$ and composite reliability, which should have a minimum value of .7 (Nunnally \& Bernstein, 1994). All factors were above .7, excluding emotional demands (.68). We checked convergent validity by measuring the average variance extracted (AVE). All indicators were above .5, indicating that the constructs can support over half of its indicators' variance (Hair et al., 2016). We also measured the Fornell-Larcker, which compares the square root of AVE values of constructs with its correlation with any other construct (Fornell \& Larcker, 1981). All square root values of AVE were higher than the correlations between constructs. Based on these tests, we justified the reliability and validity of the measurement model (Hair et al., 2011).

According to Hair et al. (2016), discriminant validity can be confirmed by cross-loading measurement and the Fornell-Larcker criterion (Fornell \& Larcker, 1981). All indicators' outer loadings on the associated constructs were greater than all their loadings on other constructs. Therefore, discriminant validity for the constructs was established, as shown in Table 4. 
Table 4

Discriminant Validity Assessment

\begin{tabular}{|c|c|c|c|c|c|c|}
\hline Constructs & WE & POS & EV & ED & M. Effect 1 & M. Effect 2 \\
\hline WE & .83 & & & -.40 & & \\
\hline POS & .62 & .88 & .84 & -.47 & .26 & .27 \\
\hline EV & .56 & & .84 & -.32 & & \\
\hline $\mathrm{ED}$ & & & & .86 & & \\
\hline M. Effect 1 & .23 & & .28 & -.21 & 1.00 & \\
\hline M. Effect 2 & .17 & & .26 & -.17 & .83 & 1.00 \\
\hline
\end{tabular}

The collinearity of the constructs was tested to ensure the path coefficients were not biased (Ong \& Bahar, 2019). We found that all values of variance inflation factor (VIF) were below 5, as indicated by VIF guidelines to ensure that the model has non-collinearity (Hair et al., 2016; Ong \& Bahar, 2019).

\section{Hypothesis Testing}

To assess the structural model, as suggested by Ong and Bahar (2019), we conducted the bootstrapping procedure developed by Preacher and Hayes (2008) to estimate the significance of the path coefficient. The bootstrapping was conducted for 155 cases and 5,000 samples. This allows the standard error estimation to determine the significance of the path coefficients. To measure the accuracy of the model's prediction, we used $\mathrm{R}^{2}$ (Figure 2). The value of $\mathrm{R}^{2}$ was .42 , indicating that the model was around a moderate level. Moreover, as shown in Figure 2, we also examined the model's predictive relevance with the $\mathrm{Q}^{2}$ value (Geisser, 1974; Stone, 1974) derived from the blindfolding procedure. The value should exceed 0 . Our results showed that the value of $\mathrm{Q}^{2}$ was .28. According to Hair et al. (2011), this demonstrated that the model has prediction relevance. POS $(\beta=.42, p<.001)$ and emotional demands $(\beta=-.14, p<.05)$ were positively correlated and statistically significant as predictors of work engagement, while the other hypotheses were not supported (Table 5).

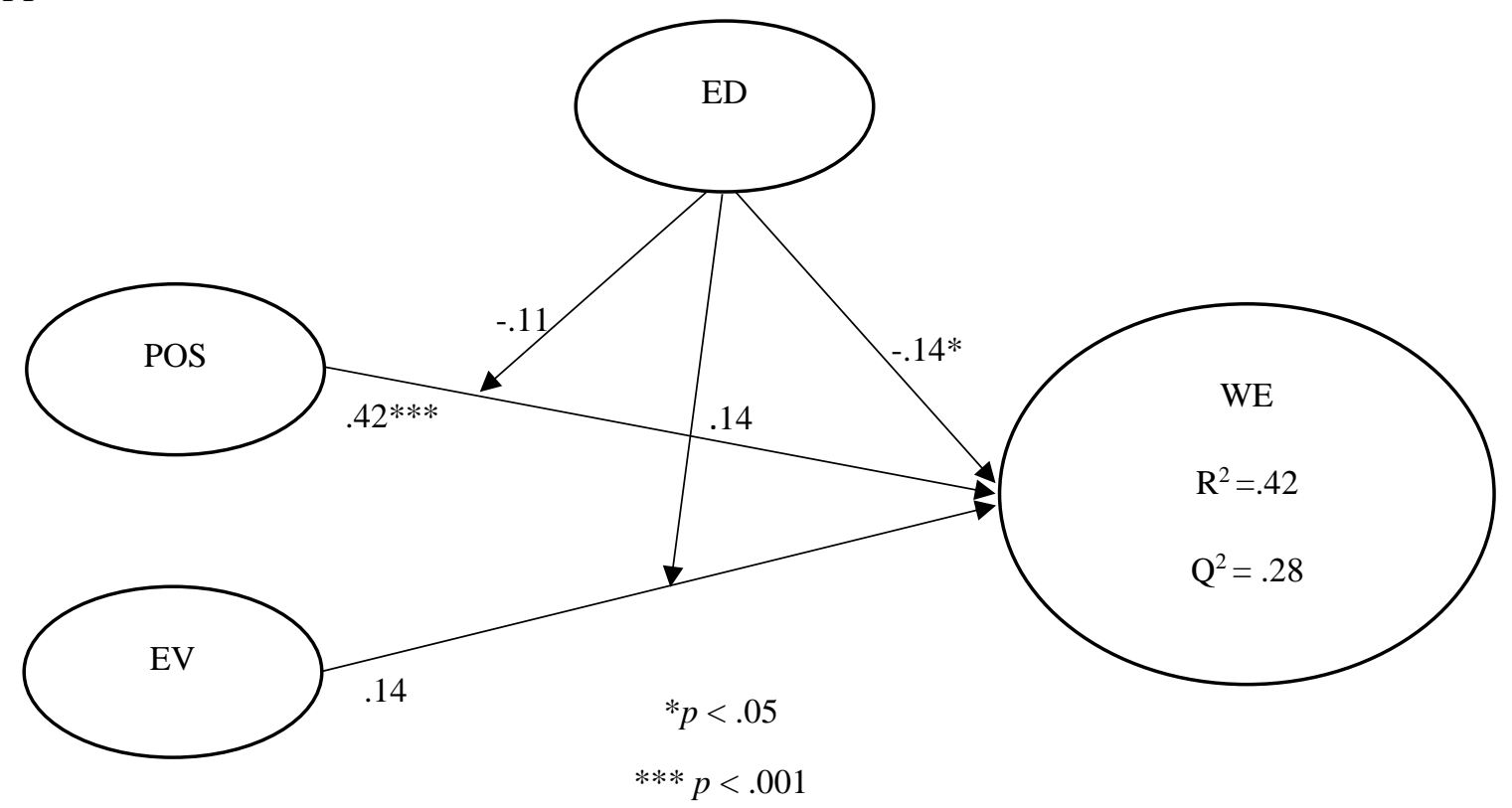

Figure 2. Results of hypothesis testing. 
Table 5

Structural Model Assessment and Hypotheses Test

\begin{tabular}{llllll}
\hline Hypothesis & Path & $\beta$ & $S E$ & $p$ & Decision \\
\hline H1 & POS --> WE & .42 & .11 & .00 & Supported \\
H2 & EV --> WE & .14 & .11 & .18 & Not supported \\
H3 & ED --> WE & -.14 & .06 & .03 & Supported \\
H4 & M. effect 1 & .14 & .09 & .14 & Not supported \\
H5 & M. effect 2 & -.11 & .08 & .19 & Not supported \\
\hline
\end{tabular}

Note: M. Effect 1: emotional demands to the relation of employee voice and work engagement; M. Effect 2: emotional demands to relation of POS and work engagement

We conducted a multi-group analysis focusing on private and public sectors (Table 6). There were no significant differences in all paths analyzed between employees in private and public sectors. However, POS for private sector employees showed a significant positive relationship with work engagement, while for public sector employees, there was no significant correlation.

Table 6

Multi-group Analysis

\begin{tabular}{|c|c|c|c|c|c|c|c|c|}
\hline \multirow[t]{2}{*}{ Indicators } & $\beta$ & $\beta$ & $\beta$ & $S E$ & $S E$ & $p$ & $p$ & $p$ \\
\hline & Private vs Public & Private & Public & Private & Public & private & public & Private vs Public \\
\hline POS --> WE & .39 & .67 & .27 & .19 & .17 & .00 & .12 & .12 \\
\hline EV --> WE & -.13 & .11 & .24 & .17 & .16 & .50 & .14 & .57 \\
\hline ED --> WE & .06 & -.10 & -.16 & .10 & .09 & .30 & .06 & .66 \\
\hline M. Effect 1 & -.12 & .09 & .21 & .16 & .13 & .58 & .11 & .54 \\
\hline M. Effect 2 & -.06 & -.19 & -.13 & .18 & .13 & .28 & .31 & .77 \\
\hline
\end{tabular}

Note. M. Effect 1: emotional demands to the relation of employee voice and work engagement; M. Effect 2: emotional demands to relation of POS and work engagement

\section{Discussion}

This study has successfully answered whether JD-R can be applied to the work engagement of young and highly educated employees in both the private and public sectors. There are at least three contributions related to the JD-R model.

First, this study extends the JD-R model by demonstrating that the role of POS as a resource for work engagement is limited only in the private sector. One possible reason is the bureaucratic nature of the public sector (Boyne, 2002), which is more strict in public sectors than in private sectors. The strict rules and regulations in public sectors may constrain line managers to support their employees (Byrne \& MacDonagh, 2017). Especially in the Indonesian context, national rules and regulations for a public servant are applied to every public servant in Indonesia, limiting the kind of support organizations may provide for their employees. POS may not be perceived as a resource for employees in public sectors.

Second, this study shows that employee voice is not perceived as job resources, and this result is consistent both in the private and public sectors. This result is surprising given employee voice is argued as access to decision making and thus provides employees with resources (Byrne \& MacDonagh, 2017). Conway et al. (2016) confirmed that argument and demonstrated that employee voice is significantly related to work engagement. The results of this study challenge that assumption. This study shows that, for the current data context in Indonesia, employee voice has no relationship with work engagement. One possible reason is that many individuals in our sample may not feel secure speaking up or may feel unable to change the working environment due to the power imbalance found in Indonesia (Riantoputra et al., 2016). They may prefer not to speak up. Moreover, many of them do not have a lot of experience in their workplace, which may infer the relative power imbalance between these young workers and their senior counterparts. In other 
words, this study extends the JD-R model by demonstrating that what is regarded as resources may not be identical across cultures.

Third, this study contributes to the JD-R model by demonstrating that job demands are perceived more as stress (not as challenges). That is, highly educated young employees perceive emotional demands as a stressor rather than an opportunity. Previous research indicates that, compared to their older counterparts, young employees tend to have less emotional regulation in relation to high workload (Carstensen et al., 1999; Charles et al., 2001; Mauno et al., 2013). In the same vein, in other studies, young employees may experience more stress at work due to less coping resources and less working experiences than the older employees (Aldwin \& Levenson, 2001; Barnes-Farrell et al., 2002; Diehl et al., 1996).

Furthermore, our results revealed that emotional demands did not moderate the relationships between job resources and engagement. This may be because the perception of emotional demands ranges within the moderate level for these groups of individuals. Prior research indicates that high demands may result in strong correlations between job resources and work engagement (e.g., Bakker et al., 2007).

\section{Limitations and Suggestions for Future Research}

This study had some limitations. In the present cross-sectional design, we were unable to test causality. Future research may want to employ other research design, such as longitudinal research or experimental study. In addition, the sample size was relatively small, which makes the discussion relatively limited. Furthermore, our analysis focused on only a few types of job resources and demands. Future research should incorporate other types of job demands and resources that potentially affect the engagement of highly educated young employees.

\section{Implications}

This study found that the types of job resources and demands that correlate with work engagement may vary for different individuals. We found that our results partially confirm the findings of prior studies, especially for employee voice. It implies that the applicability of this theory depends on the types of individuals or even types of workplaces. Therefore, it indicates that every organization needs to identify what types of resources their employees potentially need.

Our findings suggest that organizations need to support employees in order to produce engaged employees, including providing feedback and help, and also to support employees "to apply their full capabilities at work" (Bakker et al., 2011). Furthermore, organizations should pay more attention to younger employees' ability to handle problems related to high workloads. In other words, organizations need to use different stress management interventions (e.g., part-time work, other forms of flexible scheduling, skill development, training) for older and younger employees and try to prevent breaches of the psychological contract by suiting human resource practices (Peterson \& Spiker, 2005) to employees' age-related needs (Bal et al., 2008) and personal goals (Mauno et al., 2013)

\section{Conclusions}

This study confirms that the JD-R model is partially applicable to highly educated young employees in Indonesia. Specifically, POS and emotional demands are significantly related to work engagement. However, employee voice is not related to work engagement, indicating that employee voice is not regarded as a resource for young highly educated employees in Indonesia. The current 
study demonstrates that young and highly educated employees in Indonesia tend to perceive demands as stressors, not as opportunities or challenges to grow. This tendency is related to the extent to which employees are willing to engage in their work. Finally, the current study has advanced the JD-R model by demonstrating that it tends to be more applicable in private sectors than in the public sector in Indonesia.

\section{References}

Akkermans, J., Brenninkmeijer, V., Van Den Bossche, S. N., Blonk, R. W., \& Schaufeli, W. B. (2013). Young and going strong? A longitudinal study on occupational health among young employees of different educational levels. Career Development International, 18(4), 416-435.

Aldwin, C. M., \& Levenson, M. R. (2001). Stress, coping, and health at mid-life. The Handbook of Midlife Development, 188214.

Arrowsmith, J., \& Parker, J. (2013). The meaning of 'employee engagement'for the values and roles of the HRM function. The international journal of Human Resource management, 24(14), 2692-2712.

Avery, D. R., McKay, P. F., \& Wilson, D. C. (2007). Engaging the aging workforce: The relationship between perceived age similarity, satisfaction with coworkers, and employee engagement. Journal of Applied Psychology, 92(6), 1542.

Bakker, A. B. (2011). An evidence-based model of work engagement. Current Directions in Psychological Science, 20(4), 265269.

Bakker, A. B., Albrecht, S. L., \& Leiter, M. P. (2011). Key questions regarding work engagement. European Journal of Work and Organizational Psychology, 20(1), 4-28.

Bakker, A. B., \& Demerouti, E. (2007). The job demands - resources model: State of the art. Journal of Managerial Psychology, 22(3), 309-328.

Bakker, A. B., Demerouti, E., \& Sanz-Vergel, A. I. (2014). Burnout and work engagement: The JD-R approach. Annual Review of Organizational Psychology and Organizational Behavior, 1(1), 389-411.

Bakker, A. B., Hakanen, J. J., Demerouti, E., \& Xanthopoulou, D. (2007). Job resources boost work engagement, particularly when job demands are high. Journal of Educational Psychology, 99(2), 274-284.

Bal, P. M., De Lange, A. H., Jansen, P. G., \& Van Der Velde, M. E. (2008). Psychological contract breach and job attitudes: A meta-analysis of age as a moderator. Journal of Vocational Behavior, 72(1), 143-158.

Barnes-Farrell, J. L., Rumery, S. M., \& Swody, C. A. (2002). How do concepts of age relate to work and off-the-job stresses and strains? A field study of health care workers in five nations. Experimental Aging Research, 28(1), 87-98.

Boyne, G. A. (2002). Public and private management: what's the difference? Journal of Management Studies, 39(1), 97-122.

Byrne, O., \& MacDonagh, J. (2017). What's love got to do with it? Employee engagement amongst higher education workers. The Irish Journal of Management, 36(3), 189-205.

Carstensen, L. L., Isaacowitz, D. M., \& Charles, S. T. (1999). Taking time seriously: a theory of socioemotional selectivity. American Psychologist, 54(3), 165-181.

Charles, S. T., Reynolds, C. A., \& Gatz, M. (2001). Age-related differences and change in positive and negative affect over 23 years. Journal of Personality and Social Psychology, 80(1), 136.

Chin, W. W. (1998). The partial least squares approach to structural equation modeling. Modern Methods for Business Research, 295(2), 295-336.

Conway, E., Fu, N., Monks, K., Alfes, K., \& Bailey, C. (2016). Demands or resources? The relationship between HR practices, employee engagement, and emotional exhaustion within a hybrid model of employment relations. Human Resource Management, 55(5), 901-917.

Crawford, E. R., LePine, J. A., \& Rich, B. L. (2010). Linking job demands and resources to employee engagement and burnout: a theoretical extension and meta-analytic test. Journal of Applied Psychology, 95(5), 834-848.

De Jonge, J., Le Blanc, P. M., Peeters, M. C., \& Noordam, H. (2008). Emotional job demands and the role of matching job resources: A cross-sectional survey study among health care workers. International Journal of Nursing Studies, 45(10), 14601469. 
Diehl, M., Coyle, N., \& Labouvie-Vief, G. (1996). Age and sex differences in strategies of coping and defense across the life span. Psychology and Aging, 11(1), 127-139.

Eisenberger, R., Huntington, R., Hutchison, S., \& Sowa, D. (1986). Perceived organizational support. Journal of Applied psychology, 71(3), 500-507.

Elfering, A., Semmer, N. K., Tschan, F., Kälin, W., \& Bucher, A. (2007). First years in job: A three-wave analysis of work experiences. Journal of Vocational Behavior, 70(1), 97-115.

Falk, R. F., \& Miller, N. B. (1992). A primer for soft modeling: University of Akron Press Akron.

Farndale, E., Van Ruiten, J., Kelliher, C., \& Hope - Hailey, V. (2011). The influence of perceived employee voice on organizational commitment: An exchange perspective. Human Resource Management, 50(1), 113-129.

Ferreira, P., Gabriel, C., Faria, S., Rodrigues, P., \& Sousa Pereira, M. (2020). What if employees brought their life to work? The relation of life satisfaction and work engagement. Sustainability, 12(7), 2743.

Fornell, C., \& Larcker, D. F. (1981). Structural equation models with unobservable variables and measurement error: Algebra and statistics. Journal of Marketing Research, 8(3), 382-388.

Geisser, S. (1974). A predictive approach to the random effect model. Biometrika, 61(1), 101-107.

Hair, Jr, J. F., Hult, G. T. M., Ringle, C., \& Sarstedt, M. (2016). A primer on partial least squares structural equation modeling (PLS-SEM). Sage publications.

Hair, J. F., Ringle, C. M., \& Sarstedt, M. (2011). PLSSEM: Indeed, a Silver Bullet. Journal of Marketing Theory and Practice, 19(2),139-152. https://doi.org/10.2753. MTP1069-6679190202.

Hakanen, J. J., Bakker, A. B., \& Demerouti, E. (2005). How dentists cope with their job demands and stay engaged: The moderating role of job resources. European Journal of Oral Sciences, 113(6), 479-487.

Hakanen, J. J., Schaufeli, W. B., \& Ahola, K. (2008). The Job Demands-Resources model: A three-year cross-lagged study of burnout, depression, commitment, and work engagement. Work and Stress, 22(3), 224-241.

Hobfoll, S. E. (1989). Conservation of resources: a new attempt at conceptualizing stress. American psychologist, 44(3), 513-524.

Hoole, C., \& Bonnema, J. (2015). Work engagement and meaningful work across generational cohorts. SA Journal of Human Resource Management, 13(1), 11.

James, J. B., McKechnie, S., \& Swanberg, J. (2011). Predicting employee engagement in an age - diverse retail workforce. Journal of Organizational Behavior, 32(2), 173-196.

Knies, E., Boselie, P., Gould-Williams, J., \& Vandenabeele, W. (2015). Special issue of International Journal of Human Resource Management: Strategic human resource management and public sector performance. The International Journal of Human Resource Management, 26(3), 421-424.

Korsakienè, R., Raišienè, A. G., \& Bužavaitè, M. (2019). Work engagement of older employees: do employee and work-related factors matter? Economics and Sociology, 10(4), 151-161.

Kristensen, T. S., \& Borg, V. (2003). Copenhagen psychosocial questionnaire (COPSOQ). Mental Health, 5(5), 5.

Kulik, C. T., Perera, S., \& Cregan, C. (2016). Engage me: The mature-age worker and stereotype threat. Academy of Management Journal, 59(6), 2132-2156.

Mauno, S., \& Minkkinen, J. (2020). Do Aging Employees Benefit from Self-Regulative Strategies? A Follow-Up Study. Research on Aging. https://doi.org/10.1177/0164027520958582

Mauno, S., Ruokolainen, M., \& Kinnunen, U. (2013). Does aging make employees more resilient to job stress? Age as a moderator in the job stressor-well-being relationship in three Finnish occupational samples. Aging and Mental Health, 17(4), 411-422.

Nguyen, L. G. T., \& Pham, H. T. (2020). Factors affecting employee engagement at not-for-profit organizations: A case in Vietnam. The Journal of Asian Finance, Economics and Business (JAFEB), 7(8), 495-507.

Nunnally, J. C., \& Bernstein, I. R. (1994). Psychometric theory 3E. Tata McGraw-hill education.

Ong, C. H., \& Bahar, T. (2019). Factors influencing project management effectiveness in the Malaysian local councils. International Journal of Managing Projects in Business. 12(4), 1146-1164.

Park, J., \& Gursoy, D. (2012). Generation effects on work engagement among US hotel employees. International Journal of Hospitality Management, 31(4), 1195-1202.

Perry, J. L., Hondeghem, A., \& Wise, L. R. (2010). Revisiting the motivational bases of public service: Twenty years of research and an agenda for the future. Public Administration Review, 70(5), 681-690.

Peterson, S. J., \& Spiker, B. K. (2005). Establishing the positive contributory value of older workers:: A positive psychology perspective. Organizational Dynamics, 34(2), 153-167. 
Preacher, K. J., \& Hayes, A. F. (2008). Asymptotic and resampling strategies for assessing and comparing indirect effects in multiple mediator models. Behavior Research Methods, 40(3), 879-891.

Rees, C., Alfes, K., \& Gatenby, M. (2013). Employee voice and engagement: Connections and consequences. The International Journal of Human Resource Management, 24(14), 2780-2798.

Reissner, S., \& Pagan, V. (2013). Generating employee engagement in a public-private partnership: Management communication activities and employee experiences. The International Journal of Human Resource Management, 24(14), 2741-2759.

Riantoputra, C. D., Maharisa, W., \& Faridhal, T. (2016). Acquiescent and defensive silence in an Indonesian context. Makara Hubs-Asia, 20(2), 122-131.

Saks, A. M., \& Gruman, J. A. (2014). What do we really know about employee engagement? Human Resource Development Quarterly, 25(2), 155-182.

Savickas, M. L. (1999). The transition from school to work: A developmental perspective. The Career Development Quarterly, 47(4), 326-336.

Schaufeli, W. B., Bakker, A. B., \& Salanova, M. (2006). The measurement of work engagement with a short questionnaire: A cross-national study. Educational and Psychological Measurement, 66(4), 701-716.

Schaufeli, W. B., Bakker, A. B., \& Van Rhenen, W. (2009). How changes in job demands and resources predict burnout, work engagement, and sickness absenteeism. Journal of Organizational Behavior: The International Journal of Industrial, Occupational and Organizational Psychology and Behavior, 30(7), 893-917.

Schaufeli, W. B., Salanova, M., González-Romá, V., \& Bakker, A. B. (2002). The measurement of engagement and burnout: A two sample confirmatory factor analytic approach. Journal of Happiness Studies, 3(1), 71-92.

Smyer, M., \& Pitt-Catsouphes, M. (2007). The meanings of work for older workers. Generations, 31(1), 23-30.

Stone, M. (1974). Cross - validatory choice and assessment of statistical predictions. Journal of the Royal Statistical Society: Series B (Methodological), 36(2), 111-133.

Vigoda-Gadot, E., Eldor, L., \& Schohat, L. M. (2013). Engage them to public service: Conceptualization and empirical examination of employee engagement in public administration. The American Review of Public Administration, 43(5), 518538. 